\title{
HOSPITAL ENVIRONMENTAL PERFORMANCE COMPARISON IN WASTE MANAGEMENT IN JAKARTA
}

\author{
Soegeng Basoeki ${ }^{1}$, I Made Putrawan ${ }^{1}$, Susi Setyawati ${ }^{1}$ \\ ${ }^{1}$ Universitas Negeri Jakarta \\ Email: soegeng.basoeki@gmail.com,putrawan.imade@unj.ac.id, \\ susi.setyawati@gmail.com
}

\begin{abstract}
Abstrak
Penelitian ini merupakan survei terhadap kinerja lingkungan rumah sakit di bidang pengelolaan limbah. Survei dilakukan di RS. Cipto Mangunkusumo, RS. Persahabatan dan RSPI Sulianti Saroso. Kinerja lingkungan Rumah Sakit akan baik jika 1) memiliki sumber daya manusia yang cukup, manajemen anggaran dan memiliki fasilitas yang baik dan teknologi lingkungan yang memadai 2) Peraturan lingkungan dipatuhi untuk menerapkan standar kualitas. Anggaran untuk pemeliharaan fasilitas pengelolaan limbah dan perekrutan sumber daya manusia outsourcing perlu ditingkatkan. Upaya untuk meningkatkan motivasi lingkungan sumber daya manusia juga perlu dilakukan untuk mencapai target kinerja yang telah ditentukan.
\end{abstract}

Kata kunci: Kinerja lingkungan, standar kualitas, pengelolaan limbah

\begin{abstract}
This study is a survey of the performance of the hospital environment in the field of waste management. Survey was conducted in RS. Cipto Mangunkusumo, RS. Persahabatan and RSPI Sulianti Saroso. Environmental performance of the Hospital would be good if 1) has sufficient human resources, budget management and have good facilities and adequate environmental technologies 2) Environmental regulations adhered to apply quality standards. The budget for the maintenance of waste management facilities and the recruitment of human resources outsourcing needs to be improved. Efforts to increase the motivation of the human resources environment also needs to be done in order to achieve predetermined performance targets
\end{abstract}

Keywords: Enviromental performance, quality standards, waste management 


\section{PENDAHULUAN}

Rumah Sakit adalah institusi pelayanan kesehatan yang menyelenggarakan pelayanan kesehatan perorangan secara paripurna yang menyediakan pelayanan rawat inap, rawat jalan, dan gawat darurat. Rumah Sakit sebagai sarana pelayanan kesehatan, tempat berkumpulnya orang sakit maupun orang sehat dapat menjadi tempat penularan penyakit serta memungkinkan terjadinya pencemaran lingkungan dan gangguan kesehatan karena menghasilkan limbah. Berdasarkan jenis pelayanan dan pengelolaannya, Rumah Sakit dapat dibedakan menjadi Rumah Sakit umum dan Rumah Sakit Khusus. Rumah Sakit Umum memberikan pelayanan kesehatan pada semua bidang dan jenis penyakit, sedangkan Rumah Sakit Khusus memberikan pelayanan utama pada satu bidang atau satu jenis penyakit tertentu berdasarkan disiplin ilmu, golongan umur, organ, jenis penyakit, atau kekhususan lainnya. Di Propinsi DKI Jakarta, Rumah Sakit milik pemerintah pusat yang termasuk dalam kriteria Rumah Sakit umum adalah RS. Persahabatan, RS. Cipto Mangunkusumo, dan RS. Fatmawati. Selanjutnya yang termasuk kriteria Rumah Sakit khusus, yaitu: RS. Penyakit Infeksi Sulianti Saroso, RS.Kanker Dharmais, RS. Pusat Otak Nasional, RS. Jantung Harapan Kita
Laporan Hasil Penilaian Program

Penilaian Peringkat Kinerja Perusahaan dalam Pengelolaan Lingkungan Hidup (PROPER) Tahun 2010 - 2011 yang telah dibuat oleh Kementerian Lingkungan Hidup menyebutkan bahwa rumah sakit yang diawasi melalui PROPER berjumlah 42, hanya $33 \%$ berperingkat Biru, sedangkan 64 $\%$ berperingkat Merah dan sisanya 3\% berperingkat Hitam.

Menurut U.S. EPA (2005), banyak Rumah Sakit secara sukarela melakukan inisiatif di bidang lingkungan, tetapi usaha mereka sering gagal karena kurangnya sistem manajemen lingkungan yang baik dan berkelanjutan dengan mengintegrasikan masalah lingkungan ke dalam kegiatan organisasi, produk dan jasa. Sistem manajemen lingkungan merupakan pendekatan baru dan sistematis untuk kinerja lingkungan yang efektif melalui pendekatan akuntabilitas, keterlibatan karyawan, komitmen pimpinan, dan pelatihan SDM.

$$
\text { Lingkungan kerja dalam }
$$

meningkatkan kualitas sumber daya manusia salah satunya yaitu memperhatikan kualitas proses manajemen tergantung pada seberapa baik organisasi diarahkan dan dikelola. Hal tersebut dapt berupa kebijakan yang dihasilkan dari gaya kepemimpinan serta self efficacy dari sumber daya manusia itu sendiri. (Putrawan, 2017). 
Menghadapi masalah-masalah limbah Rumah Sakit, banyak terdapat "kesamaan" dan "perbedaan" yang dapat dianalisa. Analisa secara komparatif (comparative analysis) dipertimbangkan sebagai satu metode penelitian yang tepat (disesuaikan dengan situasi setempat) dan dapat dilakukan dengan cepat dan murah. (Ganis, 2011).

Penelitian ini mengkhususkan pada analisa komparatif tentang kebijakan manajemen Rumah Sakit dalam meningkatkan kinerja lingkungan dalam hal pengelolaan limbah dan strategi manajemen apa yang telah dilakukan.

\section{A. Kinerja Lingkungan (Environmental Performance)}

Menurut Kuhre (1997), kinerja lingkungan adalah hasil mengelola aspekaspek lingkungan organisasi. Sedangkan menurut Sunu (2001), kinerja lingkungan adalah hasil terukur dari Sistem Manajemen Lingkungan yang berkaitan dengan pengendalian organisasi terhadap lingkungannya, berdasarkan kebijakan, sasaran dan target lingkungan ${ }^{2}$. Kebijakan lingkungan adalah pernyataan organisasi tentang niat dan prinsipnya sehubungan dengan seluruh kinerja lingkungannya yang memberikan kerangka kerja bagi tindakan dan untuk menentukan sasaran dan target lingkungan.
Sasaran lingkungan adalah tujuan lingkungan menyeluruh yang timbul dari kebijakan lingkungan yang ditetapkan sendiri oleh organisasi untuk dicapai dan dikuantifikasikan bila dapat dipraktekkan. Sedangkan target lingkungan adalah persyaratan kinerja yang rinci, dikuantifikasikan bila dapat dipraktekkan, yang berlaku bagi organisasi atau bagiannya yang timbul dari sasaran lingkungan dan yang perlu ditetapkan dan dipenuhi untuk mencapai sasaran itu. Kinerja lingkungan kuantitatif adalah hasil yang dapat diukur dari sistem manajemen lingkungan yang terkait kontrol aspek lingkungan fisiknya. Sedangkan kinerja lingkungan kualitatif adalah hasil yang dapat diukur dari hal-hal terkait dengan ukuran asset non fisik seperti prosedur, proses inovasi, motivasi dan semangat kerja yang dialami manusia pelaku kegiatan dalam mewujudkan kebijakan lingkungan organisasi, sasaran dan targetnya (Arfan Ikhsan, 2009). Indikator kinerja lingkungan secara umum terdiri dari 2 (GEMI, 1998, dalam Purwanto, 2000) yaitu:

1. Indikator lagging yaitu ukuran kinerja end-process, mengukur output hasil proses seperti jumlah polutan yang dihasilkan apakah masih dibawah baku mutu lingkungan

2. Indikator leading yaitu ukuran kinerja in-process yang mengukur 
implementasi prosedur yang dilakukan atau mengukur faktor apa yang diharapkan membawa pada perbaikan kinerja lingkungan.

\section{B. Pengelolaan Limbah Rumah Sakit}

Definisi hal-hal yang terkait dengan pengelolaan limbah Rumah Sakit adalah sebagai berikut:

1. Limbah Rumah Sakit adalah semua limbah yang dihasilkan dari kegiatan Rumah Sakit dalam bentuk padat, cair, gas.

2. Limbah padat Rumah Sakit adalah semua limbah Rumah Sakit yang berbentuk padat sebagai akibat kegiatan Rumah Sakit yang terdiri dari limbah medis padat dan non medis.

3. Limbah medis padat adalah limbah padat yang terdiri dari limbah infektius, limbah patologi, limbah benda tajam, limbah farmasi, limbah sitotoksis, limbah kimiawi, limbah radio aktif, limbah kontainer bertekanan dan limbah dengan kandungan logam berat yang tinggi.

4. Limbah padat non medis adalah limbah padat yang dihasilkan dari kegiatan Rumah Sakit di luar medis yang berasal dari dapur, perkantoran, taman dan halaman yang dapat dimanfaatkan kembali apabila ada teknologinya.
5. Limbah cair adalah semua air buangan termasuk tinja yang berasal dari kegiatan Rumah Sakit yang kemungkinan mengandung mikroorganisme, bahan kimia beracun dan radioaktif yang berbahaya bagi kesehatan.

6. Limbah gas adalah semua limbah yang berbentuk gas yang berasal dari pembakaran di Rumah Sakit seperti incenerator, dapur, perlengkapan generator, anastesi dan pembuatan obat sitotoksik.

7. Limbah infektius adalah limbah yang terkontaminasi organisme patogen yang tidak secara rutin ada di lingkungan dan organisme tersebut dalam jumlah dan virulensi yang cukup untuk menularkan penyakit pada manusia rentan.

8. Limbah sangat infektius adalah limbah berasal dari pembiakan dan stock bahan sangat infektius, otopsi, organ binatang percobaan dan bahan lain yang telah diinokulasi, terinfeksi atau kontak dengan bahan yang sangat infektius.

9. Limbah sitotoksis adalah limbah dari bahan yang terkontaminasi dari persiapan dan pemberian obat sitotoksik untuk kemoterapi kanker yang mempunyai kemampuan untuk membunuh atau menghambat pertumbuhan sel hidup. 
10. Minimilasi limbah adalah upaya yang dilakukan Rumah Sakit untuk mengurangi jumlah limbah yang dihasilkan dengan cara mengurangi bahan (reduce), menggunakan kembali limbah (reuse), dan daur ulang limbah (recycle).

\section{Kinerja Lingkungan Rumah Sakit}

Kinerja lingkungan di Rumah Sakit adalah hasil dari capaian indikator di bidang lingkungan yang telah dilakukan oleh Unit Pengelola Lingkungan yang ada di Rumah Sakit. Capaian indikator yang dilihat adalah:

1. Besaran jumlah limbah yang telah diminimasi

2. Hasil dari program dan kegiatan lingkungan yang telah dilakukan

3. Hasil dari menaati peraturan pemerintah di bidang lingkungan dengan menggunakan standar mutu yang ada.

Besaran sumber daya yang dimiliki dan strategi yang dilakukan oleh manajemen Unit Pengelola Lingkungan di Rumah Sakit dalam mencapai target-target lingkungan yang telah ditetapkan menjadi bagian yang tidak terpisahkan dalam penelitian di bidang manajemen lingkungan. Tempat penelitian adalah di DKI Jakarta dengan lokai penelitian di RS. Persahabatan, RS. Cipto Mangunkusumo, RSPI. Sulianti Saroso.
Penelitian dilaksanakan pada bulan September - Nopember 2013.

\section{METODOLOGI PENELITIAN}

Metode penelitian yang digunakan adalah penelitian survey dengan menggunakan analisis komparatif yang menghasilkan deskripsi data secara sistematis dan faktual mengenai kinerja lingkungan di Rumah Sakit. Rumah Sakit pemerintah pusat di bawah Kementerian kesehatan yang berada di Propinsi DKI Jakarta ada 7 Rumah Sakit, yaitu: RS. Persahabatan, RS. Cipto Mangunkusumo, RS. Fatmawati, RS. Penyakit Infeksi Sulianti Saroso, RS.Kanker Dharmais, RS. Pusat Otak Nasional, RS. Jantung Harapan Kita Dari 7 RS tersebut, diambil 3 Rumah Sakit sebagai subyek penelitian dengan menggunakan metode purposive sampling method (metode sampling untuk tujuan tertentu) yaitu RS. Cipto Mangunkusumo sebagai Rumah Sakit rujukan nasional yang berskala internasional dengan kapasitas tempat tidur paling banyak diantara Rumah Sakit pemerintah lain (diatas 900 tempat tidur), RS. Persahabatan sebagai Rumah Sakit umum dengan kapasitas tempat tidur berkisar 600 tempat tidur, RSPI. Sulianti Saroso sebagai Rumah Sakit khusus dengan kapasitas tempat tidur berkisar 200 tempat tidur. 


\section{HASIL DAN PEMBAHASAN}

Rumah Sakit Umum Persahabatan (RSUP) mulai beroperasi pada tanggal 20 Nopember 1963, beralamat di Jl. Raya Persahabatan No. 1 Jakarta Timur, mempunyai kapasitas 600 tempat tidur dengan rata-rata Bed Occupancy Rate (BOR) pada periode Januari-Juli 2013 sebesar 68,90\%. Produksi rata-rata timbunan sampah medis sebesar $0,19 \mathrm{~kg} / \mathrm{TT} / \mathrm{hari}$ dan sampah non medis sebesar $0,011 \mathrm{~m} 3 / \mathrm{TT} /$ hari. ${ }^{1}$ Visi RSUP di bidang lingkungan adalah "Menjadi Percontohan Kesehatan Lingkungan Rumah Sakit Terdepan di Indonesia" dengan rangkaian misi sebagai berikut:

1. Menyiapkan perangkat teknologi pencegah dan pengendali pencemaran lingkungan

2. Menerapkan prinsip-prinsip kesehatan lingkungan Rumah Sakit secara cepat dan tepat serta sistematis melalui kegiatan pengoperasian dan pemeliharaan sarana, prasarana dan peralatan kesehatan lingkungan

3. Melaksanakan konsultasi masalah kesehatan lingkungan Rumah Sakit dengan membangun kualitas SDM sanitasi yang mampu memenuhi persyaratan kompetensi yang berlaku

4. Menyediakan informasi kesehatan lingkungan secara lengkap dan akurat dan melayani penelitian dan pelatihan bidang kesehatan lingkungan Rumah Sakit

Nilai (value) yang dijadikan budaya kerja di RSUP adalah: profesional, berkualitas, inovatif, keamanan dan keselamatan. Kebijakan di bidang lingkungan yang telah diterapkan adalah

1. Meningkatkan kinerja lingkungan melalui upaya mencegah, menanggulangi dan mengendalikan berbagai sumber pencemaran dan kontaminasi lingkungan dengan menyediakan fasilitas dan teknologi pengolahan limbah

2. Melaksanakan sistem manajemen lingkungan yang terpadu secara terus menerus

3. Berupaya menaati semua peraturanperaturan lingkungan hidup sehingga menjamin Rumah Sakit sehat, aman dan nyaman

Data jumlah karyawan yang menangani pengelolaan limbah di RSUP digambarkan oleh tabel berikut:

Tabel 1.1

Jumlah SDM Pengelola Lingkungan RSUP

\begin{tabular}{|c|c|l|}
\hline Tahun & $\begin{array}{c}\text { Jumlah } \\
\text { SDM } \\
\text { (orang) }\end{array}$ & \multicolumn{1}{|c|}{ Keterangan } \\
\hline 2011 & 19 & $\begin{array}{l}\text { S2 1 orang, S1 4 } \\
\text { orang, }\end{array}$ \\
\hline
\end{tabular}




\begin{tabular}{|l|l|l|} 
& & D3 5 orang \\
\hline 2012 & 16 & $\begin{array}{l}\text { S2 1 orang, S1 4 } \\
\text { orang, } \\
\text { D3 4 orang }\end{array}$ \\
\hline 2013 & 19 & $\begin{array}{l}\text { S2 1 orang, S1 4 } \\
\text { orang, } \\
\text { D3 4 orang }\end{array}$ \\
\hline
\end{tabular}

Sumber: RSUP

Bedasarkan isu pokok dampak penting dari kegiatan RSUP yang terkait pengelolaan lingkungan hidup meliputi: Penurunan kualitas udara, Pengelolaan intensitas kebisingan, Pengelolaan limbah cair, Pengelolaan limbah padat medis dan non medis, Pengelolaan infeksi nosokomial, Penurunan kualitas air tanah, Pengelolaan penghijauan/flora darat, Pengelolaan dampak kesempatan kerja dan peluang berusaha. Upaya manajemen RSUP dalam hal pengelolaan limbah cair yang bersumber dari limbah cair domestik baik itu black water (air buangan kakus) dan grey water (air buangan bukan dari kakus) serta limbah cair medis yang dihasilkan dari ruangan laboratorium, air bekas mencuci alat medis, sisa larutan kimia hasil penelitian dan lain-lain adalah dengan jalan:

a. Membangun satu unit STP Fluidized Bed Biofilm Reactor (FBBR) dengan kapasitas $500 \mathrm{~m} 3 /$ jam untuk limbah cair domestik dan medis. b. Membangun satu unit laboratorium IPAL untuk swapantau harian.

c. Pengelolaan pada unit pre treatment STP dengan memasang bak penyaringan kasar (barscreen) untuk memisahkan sampah dan padatan lain dari limbah cair inlet dan membangun grease trap untuk memisahkan lemak/minyak dari limbah dapur.

d. Pengelolaan pada unit STP dengan membuat kran pengambilan sampel STP untuk memudahkan pengambilan sampel dan memasang flow meter limbah cair untuk mencatat debit limbah cair.

Sedangkan pengelolaan limbah oli genset dilakukan dengan memasukkan limbah oli dalam drum tertutup dan diletakkan di ruang khusus untuk pelumas sebelum diserahkan kepada perusahaan/instansi yang telah ditunjuk untuk pengangkutan dan pengelolaannya berdasarkan ijin dari Kementerian Lingkungan Hidup.

Upaya manajemen RSUP dalam mengelola limbah padat medis dan non medis adalah sebagai berikut:

a. Menyediakan tempat sampah tertutup di setiap lantai dan sudut bangunan

b. Melakukan pemisahan antara sampah padat basah dan kering 
c. Membangun bak penampungan sampah non medis di areal Rumah Sakit dalam bentuk kontainer ukuran $2,5 \mathrm{~m} \times 1,5 \mathrm{~m} \times 1 \mathrm{~m}$ dan ruang tertutup untuk sampah medis dengan ukuran $2 \mathrm{~m}$ x 1,5 m.

d. Pengelolaan sampah non medis menggunakan kantong plastik warana hitam untuk dikumpulkan dalam TPS, dikirimkan ke TPA setiap 2 hari sekali.

e. Pengelolaan sampah medis menggunakan wadah khusus untuk limbah infektius dan obat kadaluwarsa. Selanjutnya akan dibakar dalam incenerator. Abu hasil pembakaran diangkut oleh pihak ketiga yang telah ditunjuk.

f. Upaya pengelolaan dengan memaksimalkan $3 \mathrm{R}$ (reduce, reuse, recycle)

\begin{tabular}{|l|l|l|l|} 
& Lingkungan & lingkungan & Lingkungan \\
\hline 2 & Fasilitas & Fasilitas & \\
& $\begin{array}{l}\text { penunjang kerja } \\
\text { masih kurang }\end{array}$ & $\begin{array}{l}\text { penunjang } \\
\text { kerja masih } \\
\text { kurang }\end{array}$ & \\
& & kung & \\
\hline
\end{tabular}

Sumber: RSUP

Sedangkan produksi limbah di RSUP yang harus dikelola adalah sebagai berikut:

Tabel 3.

Rata-rata Produksi Limbah RSUP

\begin{tabular}{|c|l|r|l|}
\hline No. & $\begin{array}{l}\text { Jenis } \\
\text { Limbah }\end{array}$ & $\begin{array}{l}\text { Jumlah } \\
\text { Rata-rata } \\
\text { Pertahun }\end{array}$ & Keterangan \\
\hline 1 & $\begin{array}{l}\text { Sampah Padat } \\
\text { Medis }\end{array}$ & $\begin{array}{l}50.449 \mathrm{~kg} \\
\text { Data dari tahun 2009- } \\
\text { No12 }\end{array}$ \\
\hline 2 & $\begin{array}{l}\text { Sampah Padat } \\
\text { Nodis }\end{array}$ & $\begin{array}{r}194.449 \\
\mathrm{~m} 3\end{array}$ & Data dari tahun 2009- \\
\hline 3 & Limbah Cair & Data dari tahun 2009- \\
\hline
\end{tabular}

Sumber: RSUP

Fasilitas pengelolaan limbah yang dimiliki oleh RSUP adalah sebagai berikut:

Tabel 4.

Gambaran masalah dalam Fasilitas Pengelolaan Limbah RSUP pengelolaan limbah di RSUP adalah sebagai berikut:

Tabel 2.

Permasalahan dalam Pengelolaan Limbah Tahun 2010-2012

\begin{tabular}{|c|c|c|c|}
\hline No. & Tahun 2010 & $\begin{array}{l}\text { Tahun } \\
2011\end{array}$ & $\begin{array}{l}\text { Tahun } \\
2012\end{array}$ \\
\hline 1 & $\begin{array}{l}\text { Kurangnya SDM } \\
\text { Yang } \\
\text { berpengalaman di } \\
\text { Bidang }\end{array}$ & $\begin{array}{l}\text { Kurangnya } \\
\text { SDM yang } \\
\text { berpengalam } \\
\text { an } \\
\text { di bidang }\end{array}$ & $\begin{array}{l}\text { Kurangnya } \\
\text { SDM yang } \\
\text { berpengalama } \\
\mathrm{n} \\
\text { di bidang }\end{array}$ \\
\hline
\end{tabular}

\begin{tabular}{|c|c|c|c|l|}
\hline No. & Fasilitas & Jumlah & Kapasitas & Keterangan \\
\hline 1 & IPAL & 1 unit & $500 \mathrm{~m} 3 / \mathrm{jam}$ & kondisi baik \\
\hline 2 & Incenerator & 2 unit & $100 \mathrm{~kg} / \mathrm{jam}$ & 1 unit rusak \\
\hline
\end{tabular}

Sumber: RSUP

Data terkait pengelolaan limbah dengan memaksimalkan 3R (Reduce, Reuse, Recycle) adalah sebagai berikut: 
Tabel 5.

Rata-rata Produksi Limbah RSUP

\begin{tabular}{|c|c|c|c|}
\hline No. & $\begin{array}{l}\text { Jenis } \\
\text { Limbah }\end{array}$ & $\begin{array}{l}\text { Jumlah Rata- } \\
\text { rata } \\
\text { pertahun }\end{array}$ & $\begin{array}{c}\text { Keterangan } \\
(3 \mathrm{R})\end{array}$ \\
\hline 1 & $\begin{array}{l}\text { Sampah Padat } \\
\text { Medis }\end{array}$ & $50.449 \mathrm{~kg}$ & - \\
\hline 2 & $\begin{array}{l}\text { Sampah Padat } \\
\text { Non Medis }\end{array}$ & $2.001 \mathrm{~m} 3$ & $2.790 \mathrm{~kg}$ \\
\hline 3 & Limbah Cair & $\begin{array}{r}194.449 \\
\text { m3 }\end{array}$ & - \\
\hline
\end{tabular}

Sumber: RSUP

\section{Rumah Sakit Umum Cipto}

\section{Mangunkusumo}

Rumah Sakit Umum Cipto

Mangunkusumo (RSCM) beralamat di Jl. Pangeran Diponegoro No.71 Jakarta Pusat, mempunyai kapasitas 946 tempat tidur dengan rata-rata Bed Occupancy Rate (BOR) pada periode Januari-Juni 2013 sebesar $71,36 \% .^{2}$ Jumlah pengunjung dan rawat jalan rata-rata 2.735 orang/hari.

Setelah meraih akreditasi nasional dari Komite Akreditasi Rimah Sakit (KARS) pada semester 2 tahun 2012, RSCM sebagai Rumah Sakit pusat rujukan nasional pada bulan April 2013 terakreditasi internasional dari Joint Commission International (JCI) Acreditation Standards for Hospitals dengan tetap mempertahankan sertifikasi ISO 9001:2008 dan ISO 22000:2005 (Food Management System). Visi RSCM di bidang lingkungan adalah adalah "Menjadi Unit
Pelayanan Sanitasi Lingkungan yang mampu mewujudkan lingkungan Rumah Sakit memenuhi standar universal" dengan rangkaian misi sebagai berikut:

1. Menyelenggarakan kegiatan pengolahan limbah padat dan cair

2. Menyelenggarakan pelayanan pemantauan lingkunan

3. Menyelenggarakan laboratorium lingkungan guna pengendalian pencemaran

4. Menyelenggarakan kegiatan pengawasan kesehatan lingkungan Rumah Sakit

5. Menyelenggarakan kegiatan penataan taman, penghijauan dan manajemen lingkungan yang berkelanjutan

6. Mewujudkan SDM sanitasi yang memiliki keunggulan dalam kompetensi, etiak, dan berbudaya kinerja

7. Menjadi tempat pendididkan, penelitian dan pelatihan di bidang kesehatan lingkungan dan teknologi lingkungan Rumah Sakit.

Nilai (value) yang dijadikan budaya kerja di RSCM adalah: profesionalisme, integritas, kepedulian, penyempurnaan berkelanjutan, belajar dan mendidik. Data jumlah karyawan yang menangani pengelolaan limbah di RSCM digambarkan oleh tabel berikut: 
Tabel 6.

Jumlah SDM Pengelola Lingkungan RSCM

\begin{tabular}{|c|c|l|}
\hline Tahun & $\begin{array}{c}\text { Jumlah } \\
\text { SDM } \\
\text { (orang) }\end{array}$ & Keterangan \\
\hline 2013 & 21 & $\begin{array}{l}\text { S2 2 orang, S1 6 orang, } \\
\text { D3 4 orang }\end{array}$ \\
\hline
\end{tabular}

Sumber: RSCM

Upaya manajemen RSCM dalam hal pengelolaan limbah cair yang bersumber dari limbah cair domestik serta limbah cair medis yang dihasilkan dari ruangan laboratorium, air bekas mencuci alat medis, sisa larutan kimia hasil penelitian dan lain-lain adalah dengan jalan mengoptimalkan 2 unit IPAL berkapasitas 500m3/hari dan $800 \mathrm{~m} 3 /$ hari yang sudah mempunyai Ijin Pengolahan Limbah Cair (IPLC). Pemeliharaan dan perawatan mesin-mesin, pompa-pompa dan peralatan mekanikal elektrikal yang dilaksanakan secara rutin sesuai jadwal melalui kontrak servis dengan pihak ke-3 sedangkan pengoperasiannya dilaksanakan oleh operator IPAL dan petugas teknis gedung. Pengelolaan limbah padat dilakukan melalui upaya pemilahan limbah padat dengan menyediakan fasilitas tempat sampah basah, tempat sampah kering, tempat sampah infektius, wadah sitotoksik, dan wadah benda tajam/jarum suntik (safety box), kantong plastik kuning untuk sampah infektius, kantong plastik hitam untuk sampah domestik, kantong plastik ungu untuk sampah sitotoksik, kantong palstik bening untuk sampah daur ulang, kantong plastik merah untuk sampah radioaktif kantong plastik coklat untuk sampah B3 dan stiker sampah (infektius, non infektius, daur ulang, radioaktif, sitotoksik dan B3). Jumlah sampah medis selama Januari-Juni 2013 ratarata sebanyak $23.060 \mathrm{~kg} /$ bulan atau 774 $\mathrm{kg} /$ hari yang akan dibakar di incenerator yang telah berijin. Terjadi peningkatan volume sampah medis pada semester 1 tahun 2013 dibandingkan dengan periode Juli-Desember tahun 2012 yang rata-rata sebesar 631 $\mathrm{kg} / \mathrm{hari}$, penyebabnya antara lain adalah kewaspadaan universal yang tinggi dimana semakin meningkatnya pemakaian bahan medis habis pakai yang disposable.

Untuk sampah non medis rata-rata $168.439 \mathrm{~kg} / \mathrm{bulan}$ atau $5.534 \mathrm{~kg} /$ hari. Secara umum terjadi peningkatan volume sampah non medis pada semester 1 tahun 2013 dibandingkan periode Juli-Desember 2012 yang rata-rata sebesar $4.423 \mathrm{~kg} / \mathrm{hari}$ dikarenakan bertambahnya aktifitas/unit kerja baru di lingkungan RSCM dan meningkatnya jumlah kunjungan rawat.

Untuk sampah daur ulang atau sampah non medis anorganik berupa kardus, kertas, plastik rata-rata perbulan sebanyak $5.501 \mathrm{~kg}$ atau $183 \mathrm{~kg}$ perhari menurun dibandingkan periode Juli-Desember 2012 
yang rata-rata sebesar $216 \mathrm{~kg} / \mathrm{hari}$ dikarenakan pemulung yang berkeliaran di lingkungan RS. Pengelolaan limbah B3 yang dihasilkan RSCM berupa limbah fixer, developer, oli bekas, batu baterai, sludge IPAL, aki bekas, lampu TL dan abu incenerator. Limbah B3 baik cair maupun padat dikelola dengan menyerahkannya ke pihak ke-3 yakni perusahaan pengolah limbah B3 yang mempunyai sertifiikat perijinan dari instansi yang berwenang.

Untuk limbah radioaktif dengan waktu paruh tahunan, maka pembuangan limbah bekerja sama denagn BATAN, sedangkan limbah radioaktif dengan waktu paruh yang kurang dari 10 hari, disimpan dulu pada tempat penyimpanan yang aman dan dapat dibuang ke TPS sampah RSCM apabila unsur radioaktif sudah tidak ada dengan dilakukan pengukuran paparan radiasi sebelum limbah dibuang. Produksi limbah di RSCM yang harus dikelola adalah sebagai berikut:

Tabel 7.

Rata-rata Produksi Limbah RSCM

\begin{tabular}{|c|l|c|l|}
\hline No. & $\begin{array}{l}\text { Jenis } \\
\text { Limbah }\end{array}$ & $\begin{array}{r}\text { Jumlah } \\
\text { Rata-rata } \\
\text { pertahun }\end{array}$ & Keterangan \\
\hline 1 & $\begin{array}{l}\text { Sampah } \\
\text { Padat } \\
\text { Medis }\end{array}$ & 235.572 kg & $\begin{array}{l}\text { Berdasarkan rata- } \\
\text { rata } \\
19.631 \mathrm{~kg} / \mathrm{bulan}\end{array}$ \\
\hline 2 & $\begin{array}{l}\text { Sampah } \\
\text { Padat }\end{array}$ & 1.645 .332 & $\begin{array}{l}\text { Berdasarkan rata- } \\
\text { rata }\end{array}$ \\
\hline
\end{tabular}

\begin{tabular}{|c|l|l|l|} 
& Non Medis & & $137.111 \mathrm{~kg} / \mathrm{bulan}$ \\
\hline 3 & $\begin{array}{l}\text { Limbah } \\
\text { Cair }\end{array}$ & $304.789 \mathrm{~m} 3$ & $\begin{array}{l}\text { Laporan debit } \\
\text { limbah } \\
\text { tahun 2012 }\end{array}$ \\
\hline
\end{tabular}

Sumber: RSCM

Fasilitas pengelolaan limbah yang dimiliki oleh RSCM adalah sebagai berikut:

Tabel 8.

Fasilitas Pengelolaan Limbah RSCM

\begin{tabular}{|c|l|l|cc|}
\hline No. & Fasilitas & Jumlah & Kapasitas & Keterangan \\
\hline 1 & IPAL & 2 unit & $\begin{array}{c}500 \mathrm{~m} 3 / \mathrm{hari} \\
\text { dan }\end{array}$ & \\
& & & $800 \mathrm{~m} 3 / \mathrm{hari}$ & berfungsi \\
\hline 2 & Incenerator & 1 unit & $200 \mathrm{~kg} / \mathrm{jam}$ & berfungsi \\
\hline
\end{tabular}

Sumber: RSCM

\section{Rumah Sakit Khusus Penyakit Infeksi}

\section{Sulianti Saroso}

\section{Rumah Sakit Khusus Penyakit} Infeksi Sulianti Saroso (RSPI) beralamat di Jalan Baru Sunter Permai Raya Jakarta Utara dengan luas area $35.000 \mathrm{~m}^{2}$ dan luas bangunan seluruhnya $54.034 \mathrm{~m}^{2}$ merupakan Rumah Sakit khusus yang menangani pasien penyakit infeksi dengan tingkat penularannya ke manusia berpotensi tinggi. Kapasitas RSPI sebanyak 202 tempat tidur dengan Bed Dccupancy Rate (BOR) sebesar 60-70\%, dan merupakan Rumah Sakit dengan klasifikasi kelas B. Sampah medis dikelola dengan cara dibakar di incenerator sedangkan sampah padat domestik dikumpulkan lalu dibawa 
oleh Dinas Kebersihan Jakarta Utara untuk dibawa ke TPA.

Pengelolaan limbah cair dilakukan di IPAL yang telah dibuat tahun 1993 yang terletak di belakang gedung Rumah Sakit dengan pengolahan air limbah menggunakan sistem lumpur aktif (Activated Sludge System) dengan debit maksimum 195 $\mathrm{m} 3$ /hari. IPAL terdiri dari:

- Bak penampungan awal

- Bak pengendapan

- Bak equalisasi

- Bak aerasi

- Bak kimia pemberian $\mathrm{NaOH}, \mathrm{NaOCL}$ (klorinasi), dan $\mathrm{H}_{2} \mathrm{SO}_{4}$ (netralisasi)

- Bak penampungan akhir

Juga telah dipasang sand filter dan penggunaan karbon aktif untuk memanfaatkan air limbah lebih lanjut. Upaya pengelolaan limbah padat non medis dengan menyediakan 300 bak dan untuk limbah padat medis disediakan 100 bak serta pemakaian kantong plastik hitam untuk limbah padat non medis (domestik), kantong plastik kuning untuk limbah padat medis. Juga tersedia tempat sampah non medis/domestik (organik dan anorganik).

Untuk pemusnahan limbah padat non medis digunakan incenerator dengan sistem 2 burner. Incenerator juga sudah dillengkapi dengan after burner scrubber. Untuk limbah B3 yang terdiri dari abu incenerator, lampu
TL/bohlamp bekas, sludge limbah cair dan obat kadaluwarsa yang sudah dikumpulkan, pengelolaannya diserahkan kepada pihak ketiga/swasta yang sudah berijin dari instansi yang berewenang. Bagian yang bertanggung jawab dalam kegiatan pengelolaan limbah adalah Instalasi Kesehatan Lingkungan yang merupakan bagian dari struktur organisai RSPI yang bertanggung jawab dalam bidang Pengadaan air bersih, Pengelolaan air limbah, Pengelolaan sampah Rumah Sakit, Pengawasan kebersihan, Sterilisasi alat dan linen, Pemantauan kebersihan udara ruangan rumah sakit, pengawasan kebersihan ruangan, pemberantasan serangga, tikus dan vektor lainnya,dekontaminasi ruangan, pengawasan sterilisasi alat dan bahan, kegiatan sanitasi lainnya

Visi Instalasi Kesehatan Lingkungan di RSPI adalah menjadi Rumah Sakit percontohan pada keberhasilan pelaksanaan sanitasi Rumah Sakit dalam rangka mendukung pengendalian infeksi nosokomial dan konsep green hospital serta program Gerakan Indonesia Berseri Rumah Sakit Bersih, Kementerian Kesehatan RI. Misi yang akan dituju adalah:

1. Dicapainya efektitas, efisiensi dan kualitas optimal pelayanan pemeliharaan kebersihan dan kesehatan sarana lingkungann Rumah Sakit 
2. Melaksanakan kegiatan pengawasan penyehatan ruang dan bangunan Rumah Sakit, penyehatan makanan/minuman, penyehatan air, pengendalian serangga, tikus dan binatang pengganggu, disinfekatsi dan sterilisasi, pengamanan dampak radiasi

3. Melaksanakan upaya promosi kesehatan dari aspek kesehatan lingkungan dengan berpedoman pada standar keselamatan dan kesehatan kerja

Jenis dampak yang terkait pengelolaan limbah dipantau melalui:

1. Pemantauan kualitas air limbah dengan parameter tingkat $\mathrm{BOD}, \mathrm{COD}, \mathrm{TSS}, \mathrm{pH}$ dan bakteri E.coli yang terkandung dalam air limbah di saluran drainase setiap bulan

2. Pemantauan kualitas emisi buangan dari incenerator,genset dan kendaraan dinas dengan parameter kandungan $\mathrm{N}_{\mathrm{ox}}, \mathrm{S}_{\mathrm{ox}}$ dan CO setiap 3 bulan dan 6 bulan.

3. Pemantauan volume sampah padat dilakukan setiap hari di bak-bak penampungan sampah dan incenerator.

Jumlah SDM sebanyak 8 orang yang terdiri dari 5 orang SDM teknis yang berpendidikan D3 Kesehatan Lingkungan, 1 orang staff berbendidikan S1, 2 orang honorer berpendidikan setingkat SMA. Tenaga out sourcing sebanyak 40 orang sebagai Cleaning Service. Produksi limbah di
RSPI yang harus dikelola adalah sebagai berikut:

Tabel 9.

Rata-rata Produksi Limbah RSPI

\begin{tabular}{|c|l|c|}
\hline No. & Jenis Limbah & $\begin{array}{c}\text { Jumlah Rata-rata } \\
\text { pertahun }\end{array}$ \\
\hline 1 & $\begin{array}{l}\text { Sampah Padat } \\
\text { Medis }\end{array}$ & $11.240 \mathrm{~kg}$ \\
\hline 2 & $\begin{array}{l}\text { Sampah Padat } \\
\text { Non Medis }\end{array}$ & $78.290 \mathrm{~kg}$ \\
\hline 3 & Limbah Cair & $63.875 \mathrm{~m} 3$ \\
\hline
\end{tabular}

Sumber: RSPI

Fasilitas pengelolaan limbah yang dimiliki oleh RSPI adalah sebagai berikut:

Tabel 10.

Fasilitas Pengelolaan Limbah RSPI

\begin{tabular}{|c|r|r|l|l|}
\hline No. & Fasilitas & Jumlah & Kapasitas & Keterangan \\
\hline 1 & IPAL & 1 unit & $200 \mathrm{~m} 3 / \mathrm{hari}$ & berfungsi \\
\hline 2 & Incenerator & 1 unit & $100 \mathrm{~kg} / \mathrm{jam}$ & berfungsi \\
\hline
\end{tabular}

Sumber: RSPI

Secara umum, dari tiga Rumah Sakit yang menjadi lokasi penelitian belum ada yang mempunyai sertifkat internasional di bidang manajemen lingkungan setara ISO 14000 series. Hanya RSCM yang sudah terakreditasi internasional dari Joint Commission International (JCI) Acreditation Standards for Hospitals dengan tetap mempertahankan sertifikasi ISO 9001:2008 untuk Quality Management System dan ISO 22000:2005 untuk Food Management 
System. Hal ini dikarenakan beberapa hal sebagai berikut:

1. Ketidaksiapan dan kegamangan manajemen dalam memenuhi persyaratan yang harus dipenuhi untuk memperoleh sertifikat lingkungan berstandar internasional
2. Belum dirasakan perlu karena sistem manajemen lingkungan sudah diterapkan meskipun tidak bersertifikasi internasional.

Jumlah limbah Rumah Sakit yang diminimasi dengan prinsip 3R per tahun adalah sebagai berikut:

Tabel 11.

Jumlah Limbah Rumah Sakit yang Diminimasi (3R)

\begin{tabular}{|c|l|r|r|r|r|r|r|}
\hline \multirow{2}{*}{ No. } & \multirow{2}{*}{ Jenis Limbah } & \multicolumn{2}{|c|}{ RSUP } & \multicolumn{2}{c|}{ RSCM } & \multicolumn{2}{c|}{ RSPI } \\
\cline { 3 - 8 } & Jumlah & $\%$ & Jumlah & $\%$ & Jumlah & $\%$ \\
\hline 1 & $\begin{array}{l}\text { Sampah Padat } \\
\text { Medis }\end{array}$ & - & - & - & - & - & - \\
\hline 2 & $\begin{array}{l}\text { Sampah Padat } \\
\text { Non Medis } \\
\text { (bahan } \\
\text { anorganik } \\
\text { berupa kardus, } \\
\text { kertas, plastik) }\end{array}$ & $2.790 \mathrm{~kg}$ & - & $\begin{array}{r}66.012 \\
\mathrm{~kg}\end{array}$ & 4,1 & $2.160 \mathrm{~kg}$ & 3 \\
\hline 3 & Limbah Cair & - & - & - & & & - \\
\hline
\end{tabular}

Sumber: Data olahan

Sedangkan perbandingan jumlah SDM dengan jumlah limbah yang harus dikelola adalah sebagai berikut:

Tabel 12.

Jumlah SDM Pengelola Limbah Rumah Sakit

\begin{tabular}{|c|c|c|c|c|c|c|c|}
\hline \multirow{2}{*}{ No } & \multirow{2}{*}{ Jenis Limbah } & \multicolumn{2}{|c|}{ RSUP } & \multicolumn{2}{|l|}{ RSCM } & \multicolumn{2}{|c|}{ RSPI } \\
\hline & & Limbah & SDM & Limbah & SDM & Limbah & SDM \\
\hline 1 & $\begin{array}{l}\text { Sampah Padat } \\
\text { Medis }\end{array}$ & $50.449 \mathrm{~kg}$ & \multirow{3}{*}{19} & $235.572 \mathrm{~kg}$ & \multirow{3}{*}{21} & $\begin{array}{r}11.240 \\
\mathrm{~kg} \\
\end{array}$ & \multirow{3}{*}{8} \\
\hline 2 & $\begin{array}{l}\text { Sampah Padat } \\
\text { Non Medis }\end{array}$ & $2.001 \mathrm{~m} 3$ & & $\begin{array}{r}1.645 .332 \\
\mathrm{~kg}\end{array}$ & & $\begin{array}{r}78.290 \\
\mathrm{~kg}\end{array}$ & \\
\hline 3 & Limbah Cair & $\begin{array}{r}194.449 \\
\mathrm{~m} 3\end{array}$ & & $304.789 \mathrm{~m} 3$ & & $\begin{array}{r}63.875 \\
\mathrm{~m} 3\end{array}$ & \\
\hline
\end{tabular}

Sumber: Data Olahan

Perbandingan jumlah anggaran dengan jumlah limbah yang harus dikelola adalah sebagai berikut: 
Tabel 13

Jumlah Anggaran untuk Mengelola Limbah Unit Sanitasi di Rumah Sakit

\begin{tabular}{|c|c|c|c|c|c|c|c|}
\hline \multirow[b]{2}{*}{ No } & \multirow[b]{2}{*}{ Jenis Limbah } & \multicolumn{2}{|c|}{ RSUP } & \multicolumn{2}{|c|}{ RSCM } & \multicolumn{2}{|c|}{ RSPI } \\
\hline & & Limbah & $\begin{array}{c}\text { Angga } \\
\text { ran }\end{array}$ & Limbah & $\begin{array}{c}\text { Angga } \\
\text { ran }\end{array}$ & Limbah & $\begin{array}{c}\text { Angga } \\
\text { ran }\end{array}$ \\
\hline 1 & $\begin{array}{l}\text { Sampah } \\
\text { Padat Medis }\end{array}$ & $\begin{array}{r}50.449 \\
\mathrm{~kg} \\
\end{array}$ & \multirow{3}{*}{$\begin{array}{r}350 \\
\text { juta }- \\
400\end{array}$} & $235.572 \mathrm{~kg}$ & \multirow{3}{*}{$\begin{array}{l}\text { Lebih } \\
\text { dari } \\
\text { Rp. } 2 \\
\text { Milyar }\end{array}$} & $\begin{array}{r}11.240 \\
\mathrm{~kg} \\
\end{array}$ & \multirow[b]{2}{*}{$\begin{array}{r}400 \\
\text { juta - } \\
450\end{array}$} \\
\hline 2 & $\begin{array}{l}\text { Sampah } \\
\text { Padat Non } \\
\text { Medis }\end{array}$ & $2.001 \mathrm{~m} 3$ & & $\begin{array}{r}1.645 .332 \\
\mathrm{~kg}\end{array}$ & & $\begin{array}{r}78.290 \\
\mathrm{~kg}\end{array}$ & \\
\hline 3 & Limbah Cair & $\begin{array}{r}194.449 \\
\mathrm{~m} 3\end{array}$ & & $\begin{array}{r}304.789 \\
\mathrm{~m} 3\end{array}$ & & $\begin{array}{r}63.875 \\
\mathrm{~m} 3\end{array}$ & juta \\
\hline
\end{tabular}

Sumber: Data Olahan

Perbandingan sarana dan teknologi pengelolaan limbah di tiga Rumah Sakit adalah sebagai berikut:

Tabel 14.

Jumlah Sarana Pengelolaan Limbah Rumah Sakit

\begin{tabular}{|c|c|c|c|c|c|c|}
\hline \multirow[b]{2}{*}{$\begin{array}{l}\text { Jenis } \\
\text { Limbah }\end{array}$} & \multicolumn{2}{|c|}{ RSUP } & \multicolumn{2}{|c|}{ RSCM } & \multicolumn{2}{|c|}{ RSPI } \\
\hline & $\begin{array}{l}\text { Jumlah } \\
\text { Limbah }\end{array}$ & $\begin{array}{l}\text { Unit } \\
\text { Pengelola }\end{array}$ & $\begin{array}{l}\text { Jumlah } \\
\text { Limbah }\end{array}$ & $\begin{array}{l}\text { Unit } \\
\text { Pengelola }\end{array}$ & $\begin{array}{l}\text { Jumlah } \\
\text { Limbah }\end{array}$ & $\begin{array}{c}\text { Unit } \\
\text { Pengelola }\end{array}$ \\
\hline $\begin{array}{l}\text { Sampah } \\
\text { Padat } \\
\text { Medis }\end{array}$ & $\begin{array}{r}50.449 \\
\mathrm{~kg}\end{array}$ & $\begin{array}{r}1 \text { inc } \\
\text { Kap. } 100 \\
\text { kg/jam }\end{array}$ & $\begin{array}{r}235.572 \\
\mathrm{Kg}\end{array}$ & $\begin{array}{r}1 \mathrm{inc}, \mathrm{kap} \\
200 \mathrm{~kg} / \mathrm{jam}\end{array}$ & $\begin{array}{r}11.240 \\
\mathrm{~kg}\end{array}$ & $\begin{array}{r}1 \text { inc. } \\
\text { Kap. } 100 \\
\text { kg/jam }\end{array}$ \\
\hline $\begin{array}{l}\text { Limbah } \\
\text { Cair }\end{array}$ & $\begin{array}{r}194.449 \\
\mathrm{~m} 3\end{array}$ & $\begin{array}{r}1 \text { IPAL } \\
\text { kap. } 500 \\
\text { m3/hari }\end{array}$ & $\begin{array}{r}304.789 \\
\mathrm{~m} 3\end{array}$ & $\begin{array}{r}2 \text { IPAL kap. } \\
\text { total1300 } \\
\text { m3/hari }\end{array}$ & $\begin{array}{r}63.875 \\
\mathrm{~m} 3\end{array}$ & $\begin{array}{r}1 \text { IPAL } \\
\text { kap.500 } \\
\text { m3/hari }\end{array}$ \\
\hline
\end{tabular}

Sampah padat non medis dikelola bekerja sama dengan Suku Dinas Kebersihan

Sumber: Data Olahan

Kebutuhan SDM lingkungan untuk menangani masalah lingkungan di Rumah Sakit, khususnya masalah pengelolaan limbah baik jumlah maupun kompetensinya merupakan masalah tersendiri bagi manager Unit Sanitasi dan Lingkungan di RS. Ratarata satu orang SDM lingkungan menangani sampah padat medis sebesar $1.405 \mathrm{~kg}$ $11.218 \mathrm{~kg}$ pertahun atau $3,85 \mathrm{~kg}-30,73 \mathrm{~kg}$ perhari; sampah padat non medis sebesar $9.786 \mathrm{~kg}-1.645 .332 \mathrm{~kg}$ pertahun atau 26,8 $\mathrm{kg}-4.507,8 \mathrm{~kg}$ perhari; limbah cair sebesar $7.984 \mathrm{~m} 3$ - $14.514 \mathrm{~m} 3$ pertahun atau 21,87 $\mathrm{m} 3$ - 39,76 m3 perhari. 
Tabel 15.

Perbandingan SDM lingkungan dengan jumlah limbah Rumah Sakit

\begin{tabular}{|c|c|c|c|c|c|c|c|}
\hline \multirow[b]{2}{*}{ No. } & \multirow[b]{2}{*}{$\begin{array}{c}\text { Jenis } \\
\text { Limbah }\end{array}$} & \multicolumn{2}{|c|}{ RSUP } & \multicolumn{2}{|c|}{ RSCM } & \multicolumn{2}{|c|}{ RSPI } \\
\hline & & Limbah & $\begin{array}{l}19 \\
\text { SDM }\end{array}$ & Limbah & $\begin{array}{c}21 \\
\text { SDM }\end{array}$ & Limbah & $\begin{array}{l}8 \\
\text { SDM }\end{array}$ \\
\hline 1 & $\begin{array}{l}\text { Sampah } \\
\text { Padat Medis }\end{array}$ & $\begin{array}{r}50.449 \\
\mathrm{~kg}\end{array}$ & $\begin{array}{r}1: 2.65 \\
5 \mathrm{~kg}\end{array}$ & $\begin{array}{r}235.572 \\
\mathrm{~kg}\end{array}$ & $\begin{array}{r}1: 11 . \\
218 \\
\mathrm{~kg}\end{array}$ & $\begin{array}{r}11.240 \\
\mathrm{~kg}\end{array}$ & $\begin{array}{r}1: 1.40 \\
5 \mathrm{~kg}\end{array}$ \\
\hline 2 & $\begin{array}{l}\text { Sampah } \\
\text { Padat Non } \\
\text { Medis }\end{array}$ & $\begin{array}{r}2.001 \\
\mathrm{~m} 3\end{array}$ & $\begin{array}{r}1: 105 \\
\mathrm{~m} 3\end{array}$ & $\begin{array}{r}1.645 .332 \\
\mathrm{~kg}\end{array}$ & $\begin{array}{r}1: 78 . \\
349 \\
\mathrm{~kg}\end{array}$ & $\begin{array}{r}78.290 \\
\mathrm{~kg}\end{array}$ & $\begin{array}{r}1: 9.78 \\
6 \mathrm{~kg}\end{array}$ \\
\hline 3 & Limbah Cair & $\begin{array}{r}194.449 \\
\mathrm{~m} 3\end{array}$ & $\begin{array}{l}1: 10.2 \\
34 \mathrm{~m} 3\end{array}$ & $\begin{array}{r}304.789 \\
\mathrm{~m} 3\end{array}$ & $\begin{array}{r}1: 14 . \\
514 \\
\mathrm{~m} 3\end{array}$ & $\begin{array}{r}63.875 \\
\mathrm{~m} 3\end{array}$ & $\begin{array}{r}1: 7.98 \\
4 \mathrm{~m} 3\end{array}$ \\
\hline
\end{tabular}

Sumber: Data Olahan

Proporsi jumlah SDM dan beban kerja yang tidak ideal akan menghasilkan kinerja yang tidak maksimal dalam pengelolaan limbah. Perbandingan jumlah anggaran yang tersedia di Unit Sanitasi dan Lingkungan RSUP : RSPI : RSCM adalah $1: 1,13: 5$ sedangkan perbandingan beban kerjanya adalah $1: 0,28$ $: 3,12$.

Tabel 16.

Perbandingan Anggaran Pengelolaan Limbah dengan Jumlah Limbah Rumah Sakit dengan RSUP sebagai Pembanding

\begin{tabular}{|c|c|c|c|c|c|c|c|}
\hline \multirow[b]{2}{*}{ No. } & \multirow[b]{2}{*}{ Jenis Limbah } & \multicolumn{2}{|c|}{ RSUP } & \multicolumn{2}{|c|}{$\mathrm{RSCM}$} & \multicolumn{2}{|c|}{ RSPI } \\
\hline & & Limbah & $\begin{array}{c}\text { Angga } \\
\text { ran }\end{array}$ & Limbah & $\begin{array}{c}\text { Angga } \\
\text { ran }\end{array}$ & Limbah & $\begin{array}{c}\text { Angga } \\
\text { ran }\end{array}$ \\
\hline 1 & Sampah & 50.449 & \multirow{3}{*}{$\begin{array}{r}350 \\
\text { juta }- \\
400 \\
\text { juta } \\
\end{array}$} & 235.572 & \multirow{3}{*}{$\begin{array}{l}>2 \\
\text { milyar }\end{array}$} & 11.240 & \multirow{3}{*}{$\begin{array}{r}400 \\
\text { juta - } \\
450 \\
\text { juta }\end{array}$} \\
\hline & Padat Medis & $\mathrm{kg}$ & & $\mathrm{kg}$ & & $\mathrm{kg}$ & \\
\hline \multirow[t]{5}{*}{2} & Limbah Cair & $\begin{array}{r}194.449 \\
\mathrm{~m} 3\end{array}$ & & $\begin{array}{r}304.789 \\
\mathrm{~m} 3\end{array}$ & & $\begin{array}{r}63.875 \\
\mathrm{~m} 3\end{array}$ & \\
\hline & $\begin{array}{l}\text { Perbandingan } \\
\text { sampah } \\
\text { padat medis }\end{array}$ & 1 & \multirow[t]{2}{*}{1} & 4,67 & \multirow[t]{2}{*}{5} & 0,22 & \multirow[t]{2}{*}{1,13} \\
\hline & $\begin{array}{l}\text { Perbandingan } \\
\text { limbah cair }\end{array}$ & 1 & & 1,57 & & 0,33 & \\
\hline & $\begin{array}{l}\text { Jumlah } \\
\text { perbandingan }\end{array}$ & 2 & & 6,24 & & 0,55 & \\
\hline & & 1 & & 3,12 & & 0,28 & \\
\hline
\end{tabular}

Sumber: Data Olahan 
Tabel 17.

Perbandingan SDM lingkungan dengan jumlah limbah Rumah Sakit

\begin{tabular}{|c|c|c|c|c|c|c|c|}
\hline \multirow[b]{2}{*}{ No. } & \multirow{2}{*}{$\begin{array}{c}\text { Jenis } \\
\text { Limbah }\end{array}$} & \multicolumn{2}{|c|}{ RSUP } & \multicolumn{2}{|c|}{ RSCM } & \multicolumn{2}{|c|}{ RSPI } \\
\hline & & Limbah & $\begin{array}{l}19 \\
\text { SDM }\end{array}$ & Limbah & $\begin{array}{c}21 \\
\text { SDM }\end{array}$ & Limbah & $\begin{array}{l}8 \\
\text { SDM }\end{array}$ \\
\hline 1 & $\begin{array}{l}\text { Sampah } \\
\text { Padat Medis }\end{array}$ & $\begin{array}{r}50.449 \\
\mathrm{~kg}\end{array}$ & $\begin{array}{r}1: 2.65 \\
5 \mathrm{~kg}\end{array}$ & $\begin{array}{r}235.572 \\
\mathrm{~kg}\end{array}$ & $\begin{array}{r}1: 11 . \\
218 \\
\mathrm{~kg}\end{array}$ & $\begin{array}{r}11.240 \\
\mathrm{~kg}\end{array}$ & $\begin{array}{r}1: 1.40 \\
5 \mathrm{~kg}\end{array}$ \\
\hline 2 & $\begin{array}{l}\text { Sampah } \\
\text { Padat Non } \\
\text { Medis }\end{array}$ & $\begin{array}{r}2.001 \\
\mathrm{~m} 3\end{array}$ & $\begin{array}{r}1: 105 \\
\mathrm{~m} 3\end{array}$ & $\begin{array}{r}1.645 .332 \\
\mathrm{~kg}\end{array}$ & $\begin{array}{r}1: 78 . \\
349 \\
\mathrm{~kg}\end{array}$ & $\begin{array}{r}78.290 \\
\mathrm{~kg}\end{array}$ & $\begin{array}{r}1: 9.78 \\
6 \mathrm{~kg}\end{array}$ \\
\hline 3 & Limbah Cair & $\begin{array}{r}194.449 \\
\mathrm{~m} 3\end{array}$ & $\begin{array}{l}1: 10.2 \\
34 \mathrm{~m} 3\end{array}$ & $\begin{array}{r}304.789 \\
\mathrm{~m} 3\end{array}$ & $\begin{array}{r}1: 14 . \\
514 \\
\mathrm{~m} 3\end{array}$ & $\begin{array}{r}63.875 \\
\mathrm{~m} 3\end{array}$ & $\begin{array}{r}1: 7.98 \\
4 \mathrm{~m} 3\end{array}$ \\
\hline
\end{tabular}

Sumber: Data Olahan

Proporsi jumlah SDM dan beban kerja yang tidak ideal akan menghasilkan kinerja yang tidak maksimal dalam pengelolaan limbah. Perbandingan jumlah anggaran yang tersedia di Unit Sanitasi dan Lingkungan RSUP : RSPI : RSCM adalah 1 : 1,13 : 5 sedangkan perbandingan beban kerjanya adalah $1: 0,28: 3,12$.

Tabel 18.

Perbandingan Anggaran Pengelolaan Limbah dengan Jumlah Limbah Rumah Sakit dengan RSUP sebagai Pembanding

\begin{tabular}{|c|c|c|c|c|c|c|c|}
\hline \multirow[b]{2}{*}{ No. } & \multirow[b]{2}{*}{ Jenis Limbah } & \multicolumn{2}{|c|}{ RSUP } & \multicolumn{2}{|c|}{ RSCM } & \multicolumn{2}{|c|}{ RSPI } \\
\hline & & Limbah & $\begin{array}{c}\text { Angga } \\
\text { ran }\end{array}$ & Limbah & $\begin{array}{c}\text { Angga } \\
\text { ran }\end{array}$ & Limbah & $\begin{array}{c}\text { Angga } \\
\text { ran }\end{array}$ \\
\hline 1 & $\begin{array}{l}\text { Sampah } \\
\text { Padat Medis }\end{array}$ & $\begin{array}{r}50.449 \\
\mathrm{~kg}\end{array}$ & \multirow{2}{*}{$\begin{array}{r}350 \\
\text { juta - } \\
400 \\
\text { juta }\end{array}$} & $\begin{array}{r}235.572 \\
\mathrm{~kg}\end{array}$ & \multirow{2}{*}{$\begin{array}{l}>2 \\
\text { milyar }\end{array}$} & $\begin{array}{r}11.240 \\
\mathrm{~kg}\end{array}$ & $\begin{array}{r}400 \\
\text { juta - }\end{array}$ \\
\hline \multirow[t]{5}{*}{2} & Limbah Cair & $\begin{array}{r}194.449 \\
\mathrm{~m} 3\end{array}$ & & $\begin{array}{r}304.789 \\
\mathrm{~m} 3\end{array}$ & & $\begin{array}{r}63.875 \\
\mathrm{~m} 3\end{array}$ & $\begin{array}{l}450 \\
\text { juta }\end{array}$ \\
\hline & $\begin{array}{l}\text { Perbandingan } \\
\text { sampah } \\
\text { padat medis }\end{array}$ & 1 & \multirow[t]{2}{*}{1} & 4,67 & \multirow[t]{2}{*}{5} & 0,22 & \multirow[t]{2}{*}{1,13} \\
\hline & $\begin{array}{l}\text { Perbandingan } \\
\text { limbah cair }\end{array}$ & 1 & & 1,57 & & 0,33 & \\
\hline & $\begin{array}{l}\text { Jumlah } \\
\text { perbandingan }\end{array}$ & 2 & & 6,24 & & 0,55 & \\
\hline & & 1 & & 3,12 & & 0,28 & \\
\hline
\end{tabular}

Sumber: Data Olahan 


\section{b. Capaian Indikator Kinerja}

\section{Lingkungan}

1. Capaian Indikator Hasil (Lagging Indicator) Pemenuhan atas indikator hasil dapat dilihat dari paramater pengukuran yang dibuat oleh Tim PROPER Kementerian Lingkungan Hidup. Parameter yang digunakan oleh Kementerian Lingkungan Hidup merupakan hasil pengukuran on the spot atas titik-titik penaatan yang telah ditentukan termasuk:

i. Pemenuhan terhadap

dokumen lingkungan/ijin

lingkungan:

- Memilliki dokumen lingkungan/ijin lingkungan

- Melaksanakan ketentuan dalam dokumen/ijin lingkungan

- Melaporkan pelaksanaan dokumen lingkungan/ijin lingkungan

ii. Pengendalian pencemaran air:

- Ketaatan terhadap ijin

- Ketaatan terhadap paramater baku mutu
- Ketaatan terhadap

pelaporan

- Ketaatan terhadap ketentuan teknis yang dipersyaratkan

iii. Pengendalian pencemaran udara:

- $\quad$ Ketaatan terhadap titik penaatan pemantauan

- Ketaatan terhadap pelaporan

- Ketaatan terhadap paramater Baku Mutu Emisi

- Ketaatan terhadap ketentuan teknis yang dipersyaratkan

iv. Pemantauan pengelolaan limbah B3

- Perijinan pengelolaan limbah B3

- $\quad$ Sumber limbah B3

- Neraca limbah B3 per periode

- Temuan dan Rekomendasi

- Ketaatan terhadap ketentuan teknis yang dipersyaratkan

Hasil dari PROPER Kementerian Lingkungan Hidup tahun 2010-2012 adalah sebagai berikut: 
Tabel 19.

Capaian PROPER Rumah Sakit

\begin{tabular}{|c|l|c|c|}
\hline No & $\begin{array}{l}\text { Rumah } \\
\text { Sakit }\end{array}$ & 2010-2011 & $\mathbf{2 0 1 1 - 2 0 1 2}$ \\
\hline 1 & RSUP & Merah & Hitam \\
\hline 2 & RSCM & Merah & Merah \\
\hline 3 & RSPI & Biru & Biru \\
\hline
\end{tabular}

Sumber: Kementerian KLH

\section{Keterangan:}

a. Emas, diberikan kepada penanggung jawab usaha dan/atau kegiatan yang telah secara konsisten menunjukkan keunggulan lingkungan (environmental excellency) dalam proses produksi dan/atau jasa, melaksanakan bisnis yang beretika dan bertanggung jawab terhadap masyarakat;

b. Hijau, diberikan kepada penanggung jawab usaha dan/atau kegiatan yang telah melakukan pengelolaan lingkungan lebih dari yang dipersyaratkan dalam peraturan (beyond compliance) melalui pelaksanaan sistem pengelolaan lingkungan, pemanfaatan sumberdaya secara efisien melalui upaya 4R (Reduce, Reuse, Recycle dan Recovery), dan melakukan upaya tanggung jawab sosial $(C S R)$ dengan baik;

c. Biru, diberikan kepada penanggung jawab usaha dan/atau kegiatan yang telah melakukan upaya pengelolaan lingkungan yang dipersyaratkan sesuai dengan ketentuan dan/atau peraturan perundang-undangan;

d. Merah, diberikan kepada penanggung jawab usaha dan/atau kegiatan yang upaya pengelolaan lingkungan hidup dilakukannya tidak sesuai dengan persyaratan sebagaimana diatur dalam peraturan perundang-undangan; dan

e. Hitam, diberikan kepada penanggung jawab usaha dan/atau kegiatan yang sengaja melakukan perbuatan atau melakukan kelalaian yang mengakibatkan pencemaran dan/atau kerusakan lingkungan serta pelanggaran terhadap peraturan perundang-undangan atau tidak melaksanakan sanksi administrasi.

2. Capaian Indikator Proses (Leading

Indicator) Indikator proses merupakan pengukuran atas implementasi prosedur yang dilakukan atau mengukur faktor apa yang diharapkan memperbaiki kinerja lingkungan. Lebih banyak bersifat kualitatif daripada kuantitatif 
karena lebih menilai fungsi manajemen dan implementasi prosedur yang dilakukan berdasarkan penilaian semantik, pandangan, persepsi berdasarkan pengamatan dan penilaiannya terhadap sesuatu. Banyak hal yang dapat diukur dari indikator proses, termasuk diantaranya adalah motivasi kerja karyawan, persepsi karyawan dan kepuasan pelanggan. Berdasarkan data yang didapatkan di lokasi penelitian, sistem manajemen lingkungan sudah dipraktekkan oleh Unit Pengelola Lingkungan di ketiga Rumah Sakit, yang dapat dilihat dengan adanya:

- Kebijakan di bidang lingkungan yang merupakan komitmen

\section{Rumah Sakit}

- Visi dan misi yang jelas dan terukur di unit organisasi lingkungan

- Prosedur standar dalam mengidentifikasi masalah lingkungan yang melibatkan manajer kelas menengah di Rumah Sakit (termasuk manajer lingkungan)

- Perencanaan kegiatan

- Penentuan sasaran, target dan program lingkungan baik jangka pendek maupun jangka panjang
- Pembagian peran, tanggung jawab dan kewenangn yang jelas

- Pelatihan SDM lingkungan untuk meningkatkan kompetensinya

- Prosedur penyampaian informasi terkait masalah lingkungan yang dihadapi

- Record dan pengendalian dokumen

- Pengendalian operasional

- Prosedur antisipasi kecelakaan dan kedaruratan

- Pemantauan dan pengukuran secara berkala

- Evaluasi secara periodik terhadap pencapaian sasaran dan target di bidang lingkungan

Manajemen review atas sistem yang sudah dilaksanakan secara umum.

\section{KESIMPULAN}

Berdasarkan analisis yang telah dilakukan, diperoleh kesimpulan bahwa kinerja lingkungan Rumah Sakit akan baik apabila Unit Pengelola Lingkungan di Rumah Sakit mempunyai SDM lingkungan yang cukup, ketersediaan anggaran dan mempunyai sarana dan teknologi lingkungan yang memadai Peraturan di bidang lingkungan ditaati dengan menerapkan standar mutu. 


\section{DAFTAR PUSTAKA}

Arfan Ikhsan, Akuntansi Manajemen Lingkungan (Graha Ilmu, 2009) h.309

Ganis, A. Analisa Komparatif Tentang Pengelolaan Limbah Medis di Indonesia, Thailand dan Jepang (Tesis, Universitas Negeri Jakarta, 2011) h.22

Kuhre, W. Lee. ISO 14031 Environmental Performance Evaluation, 1997, h.22

Laporan Implementasi RKL dan RPL RSCM Sem.1 Tahun 2013

Program Penilaian Peringkat Kinerja Perusahaan dalam Pengelolaan
Lingkungan Hidup (PROPER) Tahun $2010-2011$

Putrawan, I Made. 2017. Leadership and Self-Efficacy: Its Effect on Employees Motivation. Advanced Science Letters 23 (1), 173-176.

Rumah Sakit Persahabatan, Pelaksanaan Program Kerja Insatansi Sanitasi dan Pertamanan, 2012

Sunu, P. 2001. Melindungi Lingkungan dengan Menerapkan ISO 14001, Grasindo.

U.S. EPA, 2005, Health Care Guide to Pollution Prevention Implementation Through EMS, Ohio, h.1 